\title{
PENGARUH PENDIDIKAN KEWIRAUSAHAAN, LOCUS OF CONTROL, DAN KEBUTUHAN BERPRESTASI TERHADAP PEMBENTUKAN SIKAP KEWIRAUSAHAAN MAHASISWA
}

\author{
Renny Dwijayanti, Universitas Negeri Surabaya \\ renny290686@gmail.com
}

\begin{abstract}
ABSTRAK
Penelitian ini bertujuan untuk menganalisis pengaruh pendidikan kewirausahaan di perguruan tinggi, locus of control, dan kebutuhan berprestasi terhadap pembentukan sikap kewirausahaan mahasiswa. Populasi dalam penelitian ini adalah mahasiswa angkatan 2012 jurusan pendidikan ekonomi FE UNESA dengan jumlah 264 mahasiswa dengan jumlah sampel sebanyak 159 orang. Teknik pengumpulan data yang digunakan yaitu kuesioner, wawancara, dan dokumentasi. Metode analisis menggunakan Regresi Linear Berganda. Hasil penelitian menunjukkan bahwa secara parsial pendidikan kewirausahaan berpengaruh signifikan terhadap sikap kewirausahaan, locus of control berpengaruh signifikan terhadap sikap kewirausahaan, dan kebutuhan berprestasi berpengaruh signifikan terhadap sikap kewirausahaan. Sedangkan secara simultan hasil penelitian menunjukkan bahwa pendidikan kewirausahaan, locus of control, dan kebutuhan berprestasi berpengaruh signifikan terhadap sikap kewirausahaan.

Kata kunci: pendidikan kewirausahaan, locus of control, kebutuhan berprestasi, sikap kewirausahaan.
\end{abstract}

\section{ABSTRACT}

This study analyze the influence of the implementation of entrepreneurial education in college, locus of control and need for achievement on entrepreneurial attitude among students. The population of this study are the 2012 generations of economic education students Economics Faculty of UNESA as many as 264 people with the total samples 159 people. The data collection techniques using questionnaires, interviews, and documentation. The method of analysis using Multiple Linear Regression. The results showed that partially entrepreneurship education significantly influence entrepreneurial attitudes, locus of control significantly influence entrepreneurial attitude, and need for achievement significant effect on entrepreneurial attitudes. While simultaneously the results showed that entrepreneurship education, locus of control, and the need for achievement significantly influence entrepreneurial attitudes.

Keywords: entrepreneurial attitudes, locus of control, need for achievement, entrepreneurial attitudes

\section{PENDAHULUAN}

Maraknya perdagangan global dimulai dari munculnya organisasi-organisasi internasional yang melegalkan terlaksananya perdagangan bebas dan terbentuknya 
zona-zona perdagangan bebas seperti; AFTA, NAFTA, APEC, dan sebagainya. Kesepakatan perdagangan bebas yang segera akan dilaksanakan dalam waktu dekat adalah Masyarakat Ekonomi ASEAN (ASEAN Economic Community) tahun 2015. Sikap waspada harus selalu ada akibat dampak dari perdagangan bebas tersebut. Untuk menghadapi serangan negara-negara produsen yang mempunyai nilai ekonomis yang tinggi, perlu dipersiapkan faktor-faktor ekonomi yang dapat mendukung ketangguhan perekonomian nasional dari ancaman ekspansi produk luar negeri.

Faktor ekonomi yang paling dominan dalam menghadapi tantangan tersebut adalah sumber daya manusia yang berperilaku kewirausahaan berwawasan global. Sumber daya manusia yang berperilaku kewirausahaan global akan mampu meningkatkan produktivitas perdagangan internasional sektor riil yang berdampak pada peningkatan perekonomian nasional. Dengan menumbuh kembangkan perilaku kewirausahaan global bagi para pelaku bisnis internasional, diharapkan akan menciptakan unit-unit bisnis yang tangguh, peningkatan produktivitas dan menghasilkan produk-produk inovatif yang berkualitas internasional. Untuk itu perlu dilakukan pemahaman dan tuntunan kepada para pelaku bisnis internasional untuk dapat berperilaku kewirausahaan global guna meningkatkan ketangguhan perekonomian nasional dari ancaman ekspansi ekonomi negara asing terutama ASEAN dalam waktu dekat.

Tidak dipungkiri bahwa masalah pengangguran merupakan salah satu masalah penting di suatu negara, demikian halnya di Indonesia. Pengangguran di Indonesia, hampir separuhnya disumbangkan oleh lulusan perguruan tinggi yang jumlahnya sangat banyak. Fenomena ironis yang muncul di dunia pendidikan di Indonesia adalah semakin tinggi pendidikan seseorang, probabilitas atau kemungkinan dia menjadi penganggur pun semakin tinggi. Dilihat dari tingkat pendidikan, menurut data Badan Pusat Statistik (BPS) jumlah angkatan kerja yang menganggur di Surabaya hingga akhir 2010 mencapai 200 ribu orang. Jumlah ini diprediksi akan semakin meningkat apabila tidak segera disediakan lapangan kerja baru.

Kaitannya dengan kewirausahaan adalah kewirausahaan sering dihubungkan dengan pencarian keuntungan ekonomi melalui kreatifitas dan inisiatif seseorang dalam kendala ketidakpastian lingkungan oleh sumber daya yang terbatas (Austin et.al, 2006). Dalam hal ini, kewirausahaan tidak hanya dihubungkan dengan pendirian usaha baru, tetapi juga berhubungan dengan tindakan entrepreneur dalam kepekaannya memulai sesuatu yang baru (Wennekers \& Thurik, 1999). Luasnya lingkup kewirausahaan mengarahkan pemikiran pada pentingnya penanaman budaya wirausaha bagi individu dan masyarakat luas. Bukan semata mencetak pengusaha baru, peran wirausaha juga mengarah pada penanaman kerakter-karakter positif wirausaha untuk dapat diaplikasikan individu dalam berbagai bidang kegiatan.

Perguruan tinggi sebagai institusi pendidikan yang berkompeten menghasilkan SDM yang berkualitas tentunya juga telah bersiap-siap untuk menghadapi tantangan tersebut. Sumber daya manusia dari perguruan tinggi yang berperilaku kewirausahaan diharapkan mampu untuk menjawab tantangan global yang akan terjadi. Peningkatan kualitas pembelajaran telah dilakukan oleh perguruan tinggi, salah satunya adalah penerapan kurikulum 2013. Kurikulum 2013 disiapkan untuk mencetak generasi yang siap dalam menghadapi masa 
depan. Karena itu kurikulum disusun untuk mengantisipasi perkembangan masa depan. Melalui pendekatan itu diharapkan mahasiswa memiliki kompetensi sikap, ketrampilan, dan pengetahuan jauh lebih baik. Mereka akan lebih kreatif, inovatif, dan lebih produktif, sehingga nantinya mereka bisa sukses dalam menghadapi berbagai persoalan dan tantangan, dan memasuki masa depan yang lebih baik.

Salah satu solusi yang ditawarkan pemerintah untuk mengurangi angka pengangguran adalah menciptakan lapangan kerja yang bersifat padat karya. Namun, kalangan terdidik cenderung menghindari pilihan pekerjaan ini karena preferensi mereka terhadap pekerjaan kantoran atau menjadi pegawai pemerintah lebih tinggi (Wijaya, 2008). Preferensi yang lebih tinggi didasarkan pada perhitungan biaya yang telah mereka keluarkan selama menempuh pendidikan dan mengharapkan tingkat pengembalian (rate of return) yang sebanding. Dalam keluarga, sebagian besar orang tua akan lebih bahagia dan merasa berhasil dalam mendidik anak-anaknya, apabila anak dapat menjadi pegawai pemerintah maupun karyawan swasta yang jumlah penghasilannya jelas dan kontinyu setiap bulannya. Pendidikan di Indonesia juga membentuk peserta didik menjadi karyawan atau bekerja di perusahaan. Masyarakat di Indonesia cenderung lebih percaya diri ketika bekerja pada orang lain daripada memulai usaha sendiri. Selain itu adanya kecenderungan menghindari risiko gagal dan pendapatan yang tidak tetap (Wijaya, 2008).

Kondisi riil yang dapat dilihat adalah bahwa lapangan kerja yang ada tidak memungkinkan untuk menyerap seluruh lulusan perguruan tinggi, para lulusan perguruan tinggi hendaknya mulai memilih berwirausaha sebagai pilihan karirnya. Upaya untuk mendorong hal ini mulai terlihat dilakukan oleh kalangan institusi pendidikan, termasuk perguruan tinggi. Kurikulum yang telah memasukkan pendidikan kewirausahaan atau mata kuliah kewirausahaan telah marak. Namun demikian, hasilnya masih belum terlihat. Berdasarkan studi pendahuluan yang dilakukan peneliti terlihat bahwa antusiasme mahasiswa untuk berwirausaha pada saat pelaksanaan praktek kewirausahaan sangat minim. Hal ini diketahui pada saat evaluasi akhir perkuliahan kewirausahaan yang ternyata sebagian besar mahasiswa enggan untuk berwirausaha dikarenakan sangat banyak tantangan dan rintangan pada saat berlangsungnya praktek kewirausahaan serta rasa takut akan kegagalan dan risiko pada saat memulai sebuah bisnis baru.

Sikap kewirausahaan merupakan konsep individual tentang kewirausahaan, penilaian dan kecenderungan ke arah kewirausahaan (Lindsay, 2005). Sikap juga merupakan salah satu topik penting dalam penelitian mengenai kewirausahaan. Hal ini disebabkan karena sikap kewirausahaan dinilai sebagai pendekatan yang lebih baik untuk mendeskripsikan kewirausahaan pada ciri kepribadian atau demografi (Robinson et.al, 1991). Sikap dan pengetahuan ke arah kewirausahaan dimungkinkan mampu membentuk pola pikir dan kecenderungan seseorang untuk memulai sesuatu yang baru termasuk di dalamnya kemampuan menciptakan usaha baru. Terkait dengan pembentukan sikap di lembaga pendidikan, pemberian mata kuliah kewirausahaan di lingkungan pendidikan tinggi setidaknya dapat membentuk suatu sikap kewirausahaan bagi mahasiswa yang meliputi ruang lingkup kognitif dan afektif mahasiswa. Indikator pengukuran dari variabel sikap kewirausahaan adalah 1) menghargai diri sendiri, 2) berpikir positif, dan 3) kebaruan dalam bertindak. 
Gorma et.al (dalam Heinonen \& Poikkijoki, 2006) menyebutkan tujuan pendidikan kewirausahaan adalah sebagai berikut : 1) belajar mengerti kewirausahaan, (2) belajar menjadi (entrepreneurial), dan (3) belajar menjadi wirausaha (entrepreneur). Tujuan mata pelajaran kewirausahaan adalah memberikan pengetahuan kewirausahaan, menanamkan keterampilan dan perilaku wirausaha, serta menumbuhkann semangat wirausaha. Walaupun tidak menutup kemungkinan mencapai semua tujuan kewirausahaan umumnya mencakup butir 1) dan 2) dari tujuan di atas. Banyak ahli berpendapat bahwa kesediaan menanggung risiko adalah ciri wirausaha, di mana risiko berhubungan dengan peluang. Jika orang lain melihat sebagai risiko, seorang wirausaha lebih menganggapnya sebagai peluang (Heinonen \& Poikkijoki, 2006). Oleh karena itu, perilaku wirausaha yang utama adalah kemampuan menagkap, mengevaluasi, dan mengeksploitasi peluang (Shane \& Venkataraman, 2000). Tantangan pedagogis pendidikan kewirausahaan adalah kompetensi kewirauasahaan lebih holistik (Tatiila, 2010). Oleh karena itu pendidikan kewirausahaan harus berpusat pada siswa dan memungkinkan siswa untuk belajar dari kasus kehidupan nyata. Indikator pengukuran dari variabel pendidikan kewirausahaan adalah 1) pengetahuan kewirausahaan, dan 2) kemauan untuk berwirausaha.

Studi tentang locus of control selalu terkait dengan konsep yang menunjuk pada keyakinan individu mengenai peristiwa-peristiwa yang terjadi dalam hidupnya. Larsen \& Buss (Zulkaida, 2007) mengemukakan locus of control merupakan suatu konsep yang menunjuk pada keyakinan individu mengenai peristiwa-peristiwa yang terjadi dalam hidupnya. Locus of control menggambarkan seberapa jauh seseorang memandang hubungan antara perbuatan yang dilakukannya (action) dengan akibat/hasilnya (outcome). Individu yang memiliki locus of control internal lebih dapat menyesuaikan diri dengan lingkungan dan perubahan yang terjadi dalam lingkungan tersebut. Mereka berusaha untuk dapat mengatasi masalah yang mereka hadapi dengan mencari berbagai alternatif pemecahan. Mereka menganggap akan mencapai keberhasilan apabila berusaha keras dengan segala kemampuannya. Menurut Aji et.al (2010) bahwa karakteristik individu yang mempunyai locus of control internal antara lain: kontrol (individu mempunyai keyakinan bahwa peristiwa hidupnya adalah hasil dari faktor internal/kontrol personal), mandiri (individu dalam usahanya untuk mencapai suatu tujuan atau hasil, percaya dengan kemampuan dan ketrampilannya sendiri), tanggung jawab (individu memiliki kesediaan untuk menerima segala sesuatu sebagai akibat dari sikap atau tingkah lakunya sendiri, serta berusaha memperbaiki sikap atau tingkah lakunya agar mencapai hasil yang lebih baik lagi), ekspektansi (individu mempunyai penilaian subyektif atau keyakinan bahwa konsekuensi positif akan diperoleh pada situasi tertentu sebagai imbalan tingkah lakunya). Sedangkan individu yang memiliki locus of control eksternal cenderung menganggap bahwa hidup mereka terutama ditentukan oleh kekuatan dari luar diri mereka, seperti nasib, takdir, keberuntungan, dan orang lain yang berkuasa. Indikator pengukuran dari variabel locus of control adalah 1) kemauan bekerja keras, 2) selalu membuat rencana dalam setiap aktivitas, dan 3) bertanggungjawab.

Dorongan untuk dapat mencapai tujuan tidak terlepas dari kebutuhan berprestasi (n Ach). Kebutuhan berprestasi merupakan pencapaian sesuatu yang sulit untuk menguasai, memanipulasi, atau mengorganisasi sasaran fisik, manusia, 
atau ide-ide untuk mengerjakan secara cepat dan independen, untuk menyaingin atau melebihi orang lain dan untuk meningkatkan hal-hal yang berkaitan dengan target. Pinder (Ariani, 2008). Keinginan berprestasi merupakan sebuah keinginan untuk sukses dengan memanfaatkan sumber daya atau kekuatan yang ada demi hasil yang nantinya mengalami perbaikan-perbaikan kearah yang lebih baik. McClelland (Syed \& Zeffani, 2011), kebutuhan akan berprestasi atau N-ach merupakan konsep motivasi yang diyakini langsung mempengaruhi keinginan individu untuk meningkatkan kinerja mereka, konsisten tampil atau percaya diri, berusaha untuk sukses, dan mengambil tanggung jawab lebih besar untuk basis pengetahuan dan pembelajaran. Indikator pengukuran dari variabel Kebutuhan berprestasi adalah 1) keinginan melakukan pekerjaan lebih baik, dan 2) keinginan melakukan pekerjaan lebih cepat.

Berdasarkan pemikiran dan kajian empiris di atas, maka tujuan penelitian ini adalah : 1) menganalisis secara parsial pengaruh pendidikan kewirausahaan, locus of control, dan kebutuhan berprestasi terhadap pembentukan sikap kewirausahaan mahasiswa. Dan 2) menganalisis secara simultan pengaruh pendidikan kewirausahaan, locus of control, dan kebutuhan berprestasi terhadap pembentukan sikap kewirausahaan mahasiswa.

\section{METODE PENELITIAN}

Jenis penelitian ini adalah penelitian eksplanatori (explanatory research) yaitu suatu penelitian untuk mencari dan menjelaskan hubungan kausal antar variabel. Objek penelitian ini meliputi variabel-variabel yang diteliti yaitu pendidikan kewirausahaan, locus of control, dan kebutuhan berprestasi terhadap pembentukan sikap kewirausahaan mahasiswa Jurusan pendidikan Ekonomi FE Unesa. Penelitian ini menganalisis pendidikan kewirausahaan, locus of control, dan kebutuhan berprestasi terhadap pembentukan sikap kewirausahaan mahasiswa Jurusan pendidikan Ekonomi FE Unesa.

Populasi dalam penelitian ini yaitu mahasiswa Jurusan Pendidikan Ekonomi S1 angkatan tahun 2012 yang telah menempuh mata kuliah kewirausahaan sebanyak 264 orang, sedangkan jumlah sampel yaitu sebanyak 159 orang. Teknik sampling yang digunakan dalam penelitian ini adalah propotional random sampling. Propotional random sampling adalah teknik pengambilan anggota sampel dari populasi dilakukan secara acak tanpa memperhatikan strata yang ada dalam populasi (Sugiyono, 2011).

Adapun teknik pengumpulan data yang digunakan yaitu angket, wawancara, dan dokumentasi. Sedangkan sumber data yang digunakan dalam penelitian ini diambil dari dua kategori sumber, yaitu sumber primer dan sumber sekunder. Data primer berupa data yang diperoleh langsung dari setiap responden yang terpilih sebagai sampel melalui pengisian angket penelitian. Data sekunder berupa data yang diperoleh dari dokumen-dokumen terkait dengan variabel yang diamati untuk mendukung pernyataan dan teori yang telah dibangun, sehingga dapat menunjang penelitian. Penelitian ini dirancang dengan menggunakan teknik regresi linear berganda. 


\section{HASIL PENELITIAN DAN PEMBAHASAN}

Untuk mengetahui pengaruh $\mathrm{X}_{1}, \mathrm{X}_{2}$ dan $\mathrm{X}_{3}$ terhadap $\mathrm{Y}$ secara parsial dipergunakan uji $\mathrm{t}$ dan nilai koefisien regresi. Hasil analisis pengaruh secara parsial dapat dilihat pada Tabel 1 berikut

Tabel 1 Hasil Analisis Regresi Pengaruh $X_{1}, X_{2}$, dan $X_{3}$ Terhadap $Y$

\begin{tabular}{|c|c|c|c|c|c|c|}
\hline \multicolumn{7}{|c|}{ Coefficients $^{a}$} \\
\hline \multirow{2}{*}{\multicolumn{2}{|c|}{ Model }} & \multicolumn{2}{|c|}{$\begin{array}{l}\text { Unstandardized } \\
\text { Coefficients }\end{array}$} & \multirow{2}{*}{$\begin{array}{c}\begin{array}{c}\text { Standardized } \\
\text { Coefficients }\end{array} \\
\text { Beta }\end{array}$} & \multirow[b]{2}{*}{$\mathrm{T}$} & \multirow[b]{2}{*}{ Sig. } \\
\hline & & B & Std. Error & & & \\
\hline 1 & (Constant) & .340 & 2.654 & & .128 & .898 \\
\hline & Pend. Kewirausahaan & .309 & .085 & .219 & 3.614 & .000 \\
\hline & Locus of control & .237 & .044 & .333 & 5.321 & .000 \\
\hline & Keb. berprestasi & .308 & .052 & .388 & 5.931 & .000 \\
\hline
\end{tabular}

a. Dependent Variable: sikap kewirausahaan

(Sumber : diolah peneliti, 2014)

Berdasarkan hasil analisis regresi di atas dapat disusun persamaan regresi, yaitu :

$$
\mathrm{Y}=0,340+0,309 \mathrm{X}_{1}+0,237 \mathrm{X}_{2}+0,308 \mathrm{X}_{3}+0,714 \varepsilon_{3}
$$

Persamaan tersebut menunjukkan bahwa.

a. Konstanta (a) $=0,340$ tidak dapat diintepretasikan karena mempunyai signifikansi t $0,898 \geq \alpha 0,05$.

b. Koefisien regresi $X_{1}$ sebesar 0,309 menunjukkan jika pendidikan kewirausahaan mengalami peningkatan, sedangkan variabel lain yaitu locus of control $\left(\mathrm{X}_{2}\right)$ dan kebutuhan berprestasi $\left(\mathrm{X}_{3}\right)$ konstan, maka sikap kewirausahaan (Y) akan naik sebesar 30,9\%.

c. Koefisien regresi $\mathrm{X}_{2}$ sebesar 0,237 menunjukkan jika locus of control mengalami peningkatan, sedangkan variabel lain yaitu pendidikan kewirausahaan $\left(\mathrm{X}_{1}\right)$ dan kebutuhan berprestasi $\left(\mathrm{X}_{3}\right)$ konstan, maka sikap kewirausahaan (Y) akan naik sebesar 23,7\%.

d. Koefisien regresi $\mathrm{X}_{3}$ sebesar 0,308 menunjukkan jika kebutuhan berprestasi mengalami peningkatan, sedangkan variabel lain yaitu pendidikan kewirausahaan $\left(\mathrm{X}_{1}\right)$ dan locus of control $\left(\mathrm{X}_{2}\right)$ konstan, maka sikap kewirausahaan (Y) akan naik sebesar 30,8\%.

Untuk mengetahui pengaruh $\mathrm{X}_{1}, \mathrm{X}_{2}$ dan $\mathrm{X}_{3}$ terhadap $\mathrm{Y}$ secara simultan dipergunakan uji $\mathrm{F}$ dan nilai koefisien regresi. Hasil analisis pengaruh secara simultan dapat dilihat pada Tabel 4. Dari hasil uji F pada tabel di atas dapat disimpulkan bahwa pendidikan kewirausahaan, locus of control, dan kebutuhan berprestasi secara bersama-sama berpengaruh positif signifikan terhadap sikap kewirausahaan. 
Tabel 4 Hasil Analisis Regresi Pengaruh $X_{1}, X_{2}$, dan $X_{3}$ Terhadap Y

\begin{tabular}{|ll|r|r|r|r|r|}
\hline \multicolumn{7}{|c|}{ ANOVA $^{\mathrm{b}}$} \\
\hline 1 & Sum of Squares & \multicolumn{1}{c|}{$\mathrm{df}$} & Mean Square & $\mathrm{F}$ & \multicolumn{1}{c|}{ Sig. } \\
\hline & Regression & 20.661 & 3 & 13.220 & 28.199 & $.000^{\mathrm{a}}$ \\
& Residual & 21.521 & 155 & .403 & & \\
& Total & 45.182 & 158 & & & \\
\hline
\end{tabular}

a. Predictors: (Constant), Kebutuhan Berprestasi, Pend. Kewirausahaan, Locus of control

b. Dependent Variable: Sikap Kewirausahaan

Temuan penelitian ini menunjukkan bahwa terdapat pengaruh pendidikan kewirausahaan terhadap sikap kewirausahaan mahasiswa, yang berarti hipotesis pertama dalam penelitian ini diterima. Kewirausahaan merupakan jiwa dari seseorang yang diekspresikan melalui sikap dan perilaku yang kreatif dan inovatif untuk melakukan suatu kegiatan. Dengan demikian, perlu ditegaskan bahwa tujuan pembelajaran kewirausahaan sebenarnya tidak hanya diarahkan untuk menghasilkan pebisnis atau business entrepreneur, tetapi mencakup seluruh profesi yang didasari oleh jiwa wirausaha atau entrepreneur. Artinya mata kuliah kewirausahaan perlu dirancang secara khusus untuk dapat mengembangkan karakteristik kewirausahaan, seperti kreativitas, pengambilan keputusan, kepemimpinan, jejaring sosial, manajemen waktu, dan kerjasama tim. Brockhaus \& Rae (dalam Bell, 2008). Untuk itu diperlukan perubahan sistem pendidikan kewirausahaan yang tadinya difokuskan pada orientasi pengendalian fungsional seperti, keuangan, pemasaran, sumber daya manusia dan operasi menjadi fokus pada mengembangkan jiwa kewirausahaan pada peserta didik. Sehingga tantangannya adalah bagaimana sistem pembelajaran yang dapat mengembangkan diri peserta didik mereka dalam hal keterampilan, atribut dan sekaligus karakteristik perilaku seorang wirausaha. Gibb (dalam Bell, 2008).

Farzier \& Niehm (2008) menemukan bahwa pendidikan dan pelatihan mempengaruhi persepsi orang terhadap karir kewirausahaan, dengan menyediakan kesempatan untuk mensimulasikan memulai usaha dan dengan mengamati seorang role model. Artinya pendidikan kewirausahaan tidak cukup hanya diadakan di dalam kelas dalam bentuk perkuliahan saja, melainkan harus memberikan kesempatan kepada peserta didik untuk merasakan langsung bagaimana sulitnya memulai suatu usaha, menjalankannya, dan juga memperoleh kesempatan untuk mengamati seorang role model, yaitu wirausaha yang telah menjalankan usahanya dalam bentuk pemagangan sehingga sikap untuk menampilkan perilaku wirausaha dapat dimunculkan.

Temuan penelitian ini menunjukkan bahwa terdapat pengaruh locus of control terhadap sikap kewirausahaan mahasiswa, yang berarti hipotesis kedua dalam penelitian ini diterima. Salah satu yang dapat mempengaruhi sikap berwirausaha adalah locus of control. Locus of control menggambarkan keyakinan seseorang bahwa segala sesuatu yang dikerjakan tergantung pada kemampuan dan usaha untuk mencapainya. Peningkatan locus of control internal dapat membantu individu untuk menjadi pengusaha sukses sehingga dapat memberikan kontribusi bagi pertumbuhan ekonomi suatu Negara. Birdthistle, et.al (dalam Gurol, 2006), 
meyakini bahwa pengusaha memiliki locus of control internal. Hal ini disebabkan karena seseorang yang memiliki locus of control internal terlihat lebih tekun dan ulet, pantang menyerah dalam melaksanakan tugas meskipun itu sulit (Birdthistle, 2008). Seseorang yang memiliki aspek internal percaya bahwa hasil dan perilaku mereka disebabkan faktor dari dalam dirinya. Faktor internal tersebut berupa kepercayaan pada kemampuan, minat yang lebih besar serta bersikap pantang menyerah. Hal ini disebabkan karena adanya keyakinan akan kemampuan diri dalam memilih karir yang disertai dengan keyakinan bahwa segala peristiwa dalam hidupnya, ditentukan oleh usaha dan perilakukannya sendiri.

Sejalan dengan pendapat Birdthistle, Mueller dan Thomas, et.al (dalam Gurol, 2006), meyakini bahwa pengusaha memiliki locus of control internal. Seseorang yang memiliki aspek internal percaya bahwa hasil dan perilaku mereka disebabkan faktor dari dalam dirinya. Faktor internal tersebut berupa kepercayaan pada kemampuan, minat yang lebih besar serta bersikap pantang menyerah. Banyak penelitian pada subjek telah memverifikasi locus of control sangat penting bagi pengusaha. Sebagai contoh, Gilad (dalam Gurol, 2006), menggunakan locus of control untuk membedakan pemilik bisnis yang sukses dan tidak sukses. Dan hasilnya menunjukkan bahwa pebisnis dengan locus of control internal lebih sukses dibandingkan dengan pebisnis yang mengandalkan kekuatan dari luar dirinya. Hal ini bisa saja disebabkan karena seseorang yang mengandalkan kekuatan dari luar, biasanya cepat menyerah dan putus asa apabila tidak mampu mencapai target yang direncanakan, sementara dalam dunia bisnis atau berwirausaha, seseorang harus selalu siap dalam menghadapi resiko bisnis yang terkadang tidak mampu diprediksikan. Oleh karena itu, pada gilirannya akan mendorong sikap individu untuk mengarahkan segala tenaga, usaha, dan perilakunya untuk mencapai niat berwirausaha yang diharapkan.

Temuan penelitian ini menunjukkan bahwa terdapat pengaruh kebutuhan berprestasi terhadap sikap kewirausahaan mahasiswa, yang berarti hipotesis ketiga dalam penelitian ini diterima. Need for achievement merupakan keinginan yang dimiliki oleh seseorang untuk menghadapi tantangan dan memberikan arah pada kegiatan belajar sehingga dapat mencapai kesuksesan dan keunggulan. Secara teoritis, seseorang mempunyai motivasi untuk bekerja karena adanya suatu kebutuhan akan berprestasi. Seseorang yang memiliki need for achievement yang tinggi selalu siap memikul tanggungjawab sebagai konsekuensi usahanya, berani mengambil resiko yang sudah diperhitungkan dan selalu mencari informasi untuk mengukur kemajuannya. Ciri-ciri dari need for achievement yang dikemukakan di atas sangat penting dimiliki oleh orang-orang yang ingin maju dan berkembang, khususnya bagi wirausaha. Seseorang yang memiliki need for achievement yang tinggi selalu siap memikul tanggungjawab sebagai konsekuensi usahanya, berani mengambil resiko yang sudah diperhitungkan dan selalu mencari informasi untuk mengukur kemajuannya. Ciri-ciri dari need for achievement yang dikemukakan di atas sangat penting dimiliki oleh orang-orang yang ingin maju dan berkembang, khususnya bagi wirausaha. McClelland (Indarti, 2008) telah memperkenalkan konsep kebutuhan akan prestasi sebagai salah satu motif psikologis. Need for achievement merupakan dorongan yang dimiliki oleh seseorang untuk menghadapi tantangan sehingga dapat mencapai kesuksesan dan keberhasilan. Hal ini sesuai dengan pendapat Lee (1997) bahwa kebutuhan akan prestasi dapat 
diartikan sebagai suatu kesatuan watak yang memotivasi seseorang untuk menghadapi tantangan untuk mencapai kesuksesan dan keunggulan.

Sengupta dan Debnath (1994) dalam penelitiannya di India menemukan bahwa kebutuhan akan prestasi berpengaruh besar dalam tingkat kesuksesan seorang wirausaha. Lebih spesifik, kebutuhan akan prestasi juga dapat mendorong kemampuan pengambilan keputusan dan kecenderungan untuk mengambil resiko seorang wirausaha. Semakin tinggi kebutuhan akan prestasi seorang wirausaha, semakin banyak keputusan tepat yang akan diambil. Wirausaha dengan kebutuhan akan prestasi tinggi adalah pengambil resiko yang moderat dan menyukai hal-hal yang menyediakan balikan yang tepat dan cepat. Perwujudan kebutuhan berprestasi dapat dilihat dari tampilan sikap kewirausahaan yang nantinya dapat menumbuhkan perilaku berwirausaha.

Temuan penelitian ini menunjukkan bahwa secara simultan terdapat pengaruh pendidikan kewirausahaan, locus of control, dan kebutuhan berprestasi terhadap sikap kewirausahaan mahasiswa. Gorma et.al (Heinonen \& Poikkijoki, 2006) menyebutkan tujuan pendidikan kewirausahaan adalah sebagai berikut : 1) belajar mengerti kewirausahaan, (2) belajar menjadi (entrepreneurial), dan (3) belajar menjadi wirausaha (entrepreneur). Disamping itu, salah satu tujuan mata kuliah kewirausahaan adalah memberikan pengetahuan kewirausahaan, menanamkan keterampilan dan perilaku wirausaha, serta menumbuhkann semangat wirausaha. Banyak ahli berpendapat bahwa kesediaan menanggung risiko adalah ciri wirausaha, di mana risiko berhubungan dengan peluang. Jika orang lain melihat sebagai risiko, seorang wirausaha lebih menganggapnya sebagai peluang (Heinonen \& Poikkijoki, 2006). Oleh karena itu, perilaku wirausaha yang utama adalah kemampuan menangkap, mengevaluasi, dan mengeksploitasi peluang (Shane \& Venkataraman, 2000). Dimana sejauh ini, pemberian pendidikan kewirausahaan memiliki dampak yang secara tidak langsung dapat membentuk sikap positif terhadap hal-hal yang berkaitan dengan kewirausahaan. Pada kelanjutannya akan dapat meningkatkan intensi berwirausaha mahasiswa dengan memilih wirausaha sebagai pilihan karirnya. Hal ini sesuai dengan hasil temuan penelitian dari Ali et.al (2011) yang dilakukan di enam universitas di pakistan menemukan bahwa 68\% dari mahasiswa memiliki sikap positif untuk menerima kewirausahaan sebagai pilihan karir.

Kaitannya dengan locus of control adalah individu yang telah mendapatkan pendidikan kewirausahaan diharapkan mampu untuk lebih tangguh dalam menghadapi berbagai tantangan dan resiko yang dihadapkan pada saat berwirausaha. Sebagai contoh, Gilad (Gurol, 2006), menggunakan locus of control untuk membedakan pemilik bisnis yang sukses dan tidak sukses. Dan hasilnya menunjukkan bahwa pebisnis dengan locus of control internal lebih sukses dibandingkan dengan pebisnis yang mengandalkan kekuatan dari luar dirinya. Hal ini bisa saja disebabkan karena seseorang yang mengandalkan kekuatan dari luar, biasanya cepat menyerah dan putus asa apabila tidak mampu mencapai target yang direncanakan, sementara dalam dunia bisnis atau berwirausaha, seseorang harus selalu siap dalam menghadapi resiko bisnis yang terkadang tidak mampu diprediksikan.

Kebutuhan berprestasi juga diperlukan dalam pembentukan sikap kewirausahaan. ada tiga atribut yang melekat pada seseorang yang mempunyai kebutuhan akan prestasi yang tinggi, yaitu (a) menyukai tanggung jawab pribadi 
dalam mengambil keputusan, (b) mau mengambil resiko sesuai dengan kemampuannya, dan (c) memiliki minat untuk selalu belajar dari keputusan yang telah diambil (Indarti, 2008). Dari hal tersebut dapat disimpulkan bahwa pribadi yang memiliki locus of control dan kebutuhan berprestasi yang tinggi serta telah diberikan pendidikan kewirausahaan akan mudah untuk mengambil keputusan dalam menghadapi tantangan dan mengambil resiko dalam berbisnis.

\section{SIMPULAN}

Berdasarkan hasil penelitian, maka dapat ditarik beberapa kesimpulan sebagai berikut : 1) pendidikan kewirausahaan berpengaruh positif signifikan terhadap sikap kewirausahaan mahasiswa, 2) locus of control berpengaruh positif signifikan terhadap sikap kewirausahaan mahasiswa, 3) kebutuhan berprestasi berpengaruh positif signifikan terhadap sikap kewirausahaan mahasiswa.

Dari hasil penelitian tersebut maka dapat dikemukakan saran sebagai berikut : 1) merancang kurikulum yang diarahkan untuk membentuk locus of control internal mahasiswa sehingga dapat memahami pentingnya menumbuhkan locus of control mahasiswa dalam mewujudkan sikap kewirausahaan mahasiswa. Oleh karena itu, seorang pendidik harus kreatif dan dapat menggunakan metode experimental learning dalam mata kuliah kewirausahaan sehingga dapat mengubah mindset mahasiswa dari job seeker menjadi job creator. Selain itu, pengaplikasian program yang dapat membentuk kesadaran dalam diri mahasiswa agar memacu mereka untuk berwirausaha seperti membuat testimoni dengan mendatangkan wirausahawan sukses (guest lecturer), mengunjungi perusahaanperusahaan agar mahasiswa dapat mengetahui bagaimana sepak terjang suatu perusahaan dalam mencapai kesuksesan. 2) kepada mahasiswa sebagai calon wirausahawan perlu dibekali kemampuan, keterampilan, keahlian manajemen, adopsi inovasi teknologi, maupun keahlian pemasaran melalui pengalaman langsung dalam dunia usaha. Dan untuk mencapai hal tersebut mahasiswa harus menyadari tentang pentingnya pendidikan kewirausahaan untuk peningkatan locus of control, dan kebutuhan berprestasi sehingga dapat mempengaruhi sikap mereka dalam berwirausaha.

\section{DAFTAR PUSTAKA}

Aji, Rahmanto. 2010. Hubungan Antara Locus Of Control Internal dengan Kematangan Karir pada Siswa Kelas XII SMKN 4 Purworejo. Jurnal Psikologi, (Online): 1-21, (http://eprints.undip.ac.id), diakses 10 Februari 2012.

Ali, A., Topping, K.J., Tariq, R.H. 2011. Entrepreneurial Attitudes among potential Entrepreneurs. Pak. J. Commer. Social Science, (Online), 5 (1) : 12-46, (http://www.jespk.net/Publications/Vol\%205/2.pdf), diakses 4 Oktober 2011.

Ariani, Wahyu. 2008. Need for Achievement dalam Kinerja Individu: Tinjauan Konseptual. Jurnal Ekonomi. 5(1): 106-115 
Austin, J., H. Stevenson and J. Wei Skillern. 2006. Social and Commercial Entrepreneurship : Same, diffrent or both ?. Entrepreneurship Theory and Practice. $30(1): 1-22$

Bell, Joseph R. 2008. Utilization of Problem Based-Learning in an Entrepreneurship Business Planning Course, New England Journal of Entrepreneurship, pp 53.

Birdthistle, Naomi. 2008. An examination of tertiary students' desire to found an enterprise. Journal of Education and Training. 50 (7): 552- 567.

Farzier Barbara and Linda S Neihm. 2008. FCS Students' attitudes and intentions toward entrepreneurial careers, Journal of Family and Consumer Science, Academic Research Library pg 17.

Gurol, Yonca. 2006. Entrepreneurial Characteristics Amongst University Students: Some Insights for Entrepreneurship Education and Training in Turkey. Journal of Education and Training. 48 (1): 25-38

Heinonen, J. Dan Poikkijoki S. A. 2006. An Entrepreneurial Directed Approach to Entrepreneurial Education: Mission Impossible ? Journal of Management Development. (Online). 25 (1). (http://emeraldinsight.com), diakses 4 Oktober 2011.

Indarti, Nurul dan Rostiani, Rokhima. 2008. Intensi Kewirausahaan Mahasiswa: Studi Perbandingan Antara Indonesia, Jepang dan Norwegia. Jurnal Ekonomika dan Bisnis Indonesia, 23 (4): 1-27.

Lee, S.H. \& Wong, P.K. 1997. An Exploratory Study of Technopreneurial Intentions: A Career Anchor Perspective. Journal of Business Venturing, 4(4): 1-35.

Lindsay, N.J. 2005. Toward a Cultural Model of Indigeneous Entrepreneurial Attitude. Academy of Marketing Science Review, (Online), 5 : 1-15, (http://digital.library.adelaide.edu.au/dspace/handle/2440/33668), diakses 15 Januari 2012.

Robinson P.B., Stimpson, D.V., Huefner, J.C. \& Hunt, H.K. 1991. An Attitude Approach to the Prediction of Entrepreneurship. Entrepreneurship Theory \& Practice, (Online), 15 (4) : 13-31, (http://www.mendeley.com/research /attitude-approach-prediction-entrepreneurship/), diakses 19 September 2011.

Sengupta, Sankar dan Debnath, Suraj. 1994. Need for Achievement and Entrepreneurial Success: A Study of Entrepreneurs in Two Rural Industries in West Bengal. Journal of Entrepreneurship. 3(2): 191-203

Shane, S \& Venkataraman, S. 2000. The Promise of Entrepreneurship as a Feld of Research. Academy of Management Review, 25 (1), 217-226

Sugiyono. 2011. Statistika untuk Penelitian. Bandung : Alfabeta

Syed, Ryan James dan Zeffane, Rachid M. 2011. Need For Achievement and Entrepreneurial Potential: A Study of Young Adults In the UAE. Education, Business and Society. 4 (3): 153-166 